\title{
Removing chromium and lead metals using phytoremediation technique
}

\author{
Riyad Al-Anbari ${ }^{1}$, Abdul-Hameed Al-Obaidy ${ }^{2}$, Mahmoud Al-Khafaji ${ }^{1 *}$ and Tiba Al-Imari ${ }^{1}$ \\ ${ }^{1}$ Building and Construction Engineering Dept, University of Technology, Baghdad, Iraq \\ ${ }^{2}$ Environment Research Center, University of Technology, Baghdad, Iraq
}

\begin{abstract}
Phytoremediation technique uses plants parts to remove, extract, and absorb heavy or toxic matter from soil and water. In the present study, Catharanthusroseus (Periwinkle) and Nerium Oleander (Oleander) were used for removing Chromium $(\mathrm{Cr})$ and Lead $(\mathrm{Pb})$ metals. These plant species were seeded in polyethylene pots containing $8 \mathrm{~kg}$ of soil. Each pot was irrigated with wastewater for four months (May, June, July and August) and accumulation of the considered metals was analyzed after every month for leaf, stem and root by using Atomic Absorption Spectrophotometer (AAS). This experimental work was carried out in the laboratories of Water Desalination Researches Unit - Building and Construction Engineering Department and Environmental Research Centre at the University of Technology in Baghdad City, Iraq. The concentration of $\mathrm{Cr}$ was found to be increased with time. High $\mathrm{Cr}$ concentration, $20.34 \mathrm{mg} / \mathrm{kg}$, was recorded at August in leaf of Periwinkle and $19.61 \mathrm{mg} / \mathrm{kg}$ in root of Oleander in case of using $100 \%$ wastewater (WW). While, for $\mathrm{Pb}$, the maximum concentration, $22 \mathrm{mg} / \mathrm{kg}$, was recorded in June in leaf of Periwinkle and $19.5 \mathrm{mg} / \mathrm{kg}$ in steam of Oleander. Accordingly, Oleander has the maximum removal efficiency.
\end{abstract}

\section{Introduction}

Water, air and soil pollution is the main environmental issue faced by the modern society. While, soils are considered as the major sink for toxic metals released to the environment by the mention anthropogenic activities [1]. Thus, contaminated soils and waters pose a major environmental and human health problem [2]. The heavy metals may come from natural sources, leached from rocks and soils according to their geochemical mobility or come from anthropogenic sources, as a result of human land occupation and industrial pollution [3]. Heavy metals are found soluble in water, so that, it can enter in ecosystems by water pathways [4].

So that, many researchers and environmentalists have developed cheap and good technology to remediate the pollutant through "Phytoremediation" [5]. Phytoremediation is an emerging technology that uses various plants to degrade, extract, contain, or immobilize contaminants from soil and water. This technology has received much attention lately as an innovative, costeffective alternative to the more established treatment methods used at hazardous waste sites [6]. There are several factors which are considered to select the plant for phytoremediation, one of them is that the plant should have acceptable degree of tolerance to the site conditions to grow well and should be able to accumulate numerous metal contaminants and the most important factor is that the plant species should grow quickly and should be easy to harvest [7]. Several types of phytoremediation are being used to-day Phytoextraction, Phytostabilazation, Phytovolatilization, rhizofiltration and phytodegradation.

The objective of this research is to determine the ability of Catharanthusroseus (Periwinkle) and Nerium oleander (Oleander) plants to remove Chromium $(\mathrm{Cr})$ and Lead $(\mathrm{Pb})$ ions from soil by irrigating with wastewater (WW) and to determine the effectiveness of these plants in removing these metals.

\section{Experimental works}

In order to evaluate the effect of ornamental plants, such as Periwinkle and Oleander, in the removal of $\mathrm{Cr}$ and $\mathrm{Pb}$ from soil irrigated with WW, Experimental pots were conducted during the period from May 2015 to August 2015. This experimental work was carried out in the laboratories of Water Desalination Researches Unit (WDRU) - Building and Construction Engineering Department (BCED) and Environmental Research Centre (ERC) at the University of Technology (UOT), Baghdad, Iraq. The experiment was arranged for four months to evaluate the effect of ornamental plants; Periwinkle and Oleander as shown in Plate 1, in the removal of $\mathrm{Pb}$ and $\mathrm{Cr}$ from soil irrigated with (WW). Four levels of water were used for irrigation including tap water (control) (T1), $50 \%$ of WW $+50 \%$ of tap water $(50 \% \mathrm{WW})(\mathrm{T} 2), 75 \% \mathrm{WW}+25 \%$ tap water $(75 \% \mathrm{WW})$ (T3) and $100 \% \mathrm{WW}(100 \% \mathrm{WW})(\mathrm{T} 4)$. The selected

\footnotetext{
* Corresponding author: 41100@uotechnology.edu.iq
} 
plants were planted in plastic pots (6 plant per pot; 25 $\mathrm{cm}$ length $\times 25 \mathrm{~cm}$ width $\times 25 \mathrm{~cm}$ height) filled with $8 \mathrm{~kg}$ of sandy loam soil. The pots were kept in the greenhouse of WDRU - BCED at UOT.
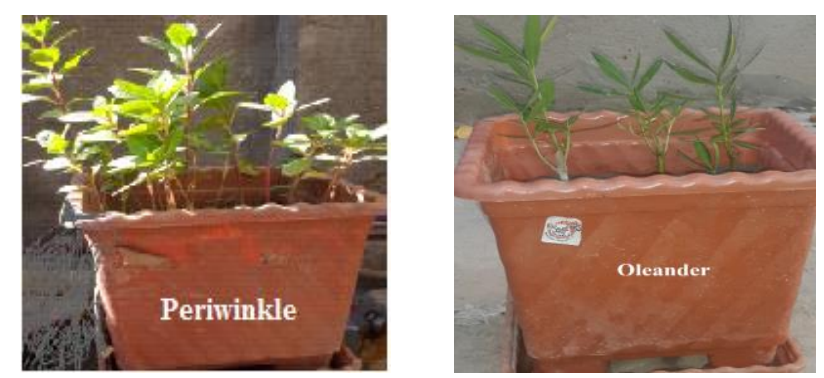

Plate 1. Tested plants.

The WW samples were collected from sewage nearby the experimental site in acid washed polyethylene containers. Potable water also collected from tap water nearby the experimental site. WW, tap water, soil and plant samples were monthly collected to determine the concentration of $\mathrm{Cr}$ and $\mathrm{Pb}$.

The soil was air-dried, powdered, sieved through a $2 \mathrm{~mm}$ sieve and $\mathrm{Cr}$ and $\mathrm{Pb}$ concentration was measured. The total concentration of soil $\mathrm{Pb}$ and $\mathrm{Cr}$ was measured using wet digestion method. The WW samples were collected in acid washed polyethylene containers. $100 \mathrm{ml}$ of WW sample has been filtered using Whatman filter paper ( $0.45 \mu \mathrm{m}$ pore size) for estimation of dissolved heavy metals $(\mathrm{Cr}$ and $\mathrm{Pb})$. Another $100 \mathrm{ml}$ of the sample have been digested with (3: 1) of Hydrochloric acid $(\mathrm{HCl})$ and Nitric acid (HNO3) to determine total heavy metals. Procedures followed for analysis have been in accordance with the standard methods for examination of water and WW [8]. Analysis of the total and dissolved of heavy metal was performed with a flame atomic absorption spectrophotometer (AA6300, Shimadza, Japan).

\section{Results and discussion}

The concentration of $\mathrm{Cr}$ and $\mathrm{Pb}$ heavy metals that were found in the parts of plants which were irrigated with WW during the experimental period (four months) is shown in Tables I and II. The measured concentrations of $\mathrm{Cr}$ in Periwinkle and Oleander plant parts are listed in Table I. The minimum concentration, $1.35 \mathrm{mg} / \mathrm{kg}$, was found in the stem of Oleander plant in May in the control treatment and the maximum concentration, 19.855 $\mathrm{mg} / \mathrm{kg}$, was observed in the leaf of the Oleander plant at $100 \% \mathrm{WW}$ in May. While the minimum concentration of $\mathrm{Cr}, 1.37 \mathrm{mg} / \mathrm{kg}$, was found in the roots of Periwinkle plants at a control treatment in May and maximum concentration was measured in Periwinkle, $20.34 \mathrm{mg} / \mathrm{kg}$, in August $\mathrm{T} 100 \% \mathrm{WW}$. However, the experimental results indicated that the Periwinkle plant can be considered as an effective plant to remove the $\mathrm{Cr}$ from soil irrigated with WW.

Table II demonstrates the results of concentration of $\mathrm{Pb}$ in leaf, stem and root of Periwinkle and Oleander. The results show that the minimum concentration, 4.7 $\mathrm{mg} / \mathrm{kg}$, was measured in May at the control treatment in the leaf of Periwinkle plant and maximum concentration, $22.00 \mathrm{mg} / \mathrm{kg}$, was observed in the leaf of Periwinkle plant in June at $100 \% \mathrm{WW}$. For Oleander plant, the maximum and minimum concentration of $\mathrm{Pb}$ was observed in leaf at $25 \% \mathrm{WW}$ in May and stem of plant at $100 \% \mathrm{~W}$ ) in June. The highest and lowest value was 4.02 and $19.5 \mathrm{mg} / \mathrm{kg}$, respectively.

The percent of removal efficiency of each heavy metal was calculated as follows:

Removal Efficiency $(\%)=\left(\frac{C_{i}-C_{f}}{C_{i}}\right) \times 100$

Where $C_{i}$ is the initial concentration of heavy metal $(\mathrm{mg} / \mathrm{kg})$ and $\mathrm{C}_{\mathrm{f}}$ is the final concentration of heavy metal (mg/kg).

Figures 1 to 4 show the removal efficiency in the level of heavy metals in plants for all treatment. The percentage of removal efficiency of $\mathrm{Cr}$ and $\mathrm{Pb}$ in the Periwinkle and Oleander for all the treatment was calculated for every month.

Figures 1 and 2 show that the maximum removal efficiency of Periwinkle to remove $\mathrm{Pb}$ from soil that was irrigated with WW was 91.08\% which occurs in August. While for Oleander it was 95.96\%. The minimum removal efficiency of Periwinkle and Oleander for removing $\mathrm{Pb}$ was $6.89 \%$ and $6.08 \%$, respectively which occurs in May.

Figures 3 and 4 illustrated that the maximum removal efficiency to remove $\mathrm{Cr}$ from soil that was irrigated by WW of Periwinkle and Oleander was $94.36 \%$ and 94.92\% which occurs in August. While the minimum was $1.82 \%$ and $2.64 \%$, respectively, this occurs in May. Generally, the removal efficiency increases with time and both Periwinkle and Oleander are good plant to remove $\mathrm{Pb}$ and $\mathrm{Cr}$ from soil irrigated with $\mathrm{WW}$.

\section{Conclusions}

In this research and from the obtained results, it can be concluded that both Periwinkle and Oleander observed in this study were very effective in removing $\mathrm{Cr}$ and $\mathrm{Pb}$ because of their acceptable percentage of removal efficiency. The efficiency of removing $\mathrm{Pb}$ for both plants, (94.36\% for Periwinkle and $94.92 \%$ for Oleander), is better than that of $\mathrm{Cr}$ which is $91.08 \%$ and 95.96\% for Periwinkle and Oleander, respectively.

Accordingly, it can be concluded that Periwinkle and Oleander have hyper accumulation properties and are good to remove heavy metals. 
Table 1. Concentration of $\mathrm{Cr}$ in plant parts during the experimental period.

\begin{tabular}{|c|c|c|c|c|c|c|c|c|c|c|c|c|}
\hline \multirow{4}{*}{ 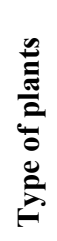 } & \multicolumn{12}{|c|}{ May } \\
\hline & \multicolumn{12}{|c|}{ Percent of WW } \\
\hline & \multicolumn{3}{|c|}{$0 \%$} & \multicolumn{3}{|c|}{$25 \%$} & \multicolumn{3}{|c|}{$75 \%$} & \multicolumn{3}{|c|}{$100 \%$} \\
\hline & 岕 & 苛 & $\begin{array}{l}\vec{\circ} \\
\stackrel{2}{\circ}\end{array}$ & 岕 & $\underset{\Xi}{\stackrel{\Xi}{\varpi ~}}$ & $\begin{array}{l}\overrightarrow{0} \\
\stackrel{0}{2}\end{array}$ & $\mid$\begin{tabular}{c}
4 \\
\multirow{J}{*}{} \\
-1
\end{tabular} & $\underset{\varpi}{\stackrel{\Xi}{\varpi ~}}$ & $\begin{array}{l}\overrightarrow{0} \\
\stackrel{0}{2}\end{array}$ & 岕 & $\begin{array}{l}\tilde{\Phi} \\
\stackrel{\varpi}{\omega}\end{array}$ & $\begin{array}{l}\vec{\circ} \\
\stackrel{2}{\circ}\end{array}$ \\
\hline 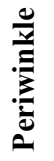 & $\stackrel{\infty}{\stackrel{\infty}{\sim}}$ & $\begin{array}{l}\stackrel{\infty}{\infty} \\
\stackrel{i}{ }\end{array}$ & $\tilde{n}$ & $\hat{n}$ & $\vec{b}$ & m़ & ก̋? & $\frac{1}{6}$ & $\stackrel{\infty}{\infty}$ & $\stackrel{n}{n}$ & $\frac{\stackrel{n}{ \pm}}{6}$ & $\underset{\sim}{\stackrel{+}{a}}$ \\
\hline 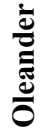 & $\begin{array}{l}0 \\
n \\
n\end{array}$ & $\stackrel{n}{m}$ & $\stackrel{m}{m}$ & ?ִ & $\begin{array}{l}\Delta \\
\text { aे }\end{array}$ & $\stackrel{\overbrace{}}{\cong}$ & 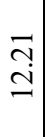 & $\stackrel{\searrow}{\stackrel{\Xi}{\Xi}}$ & $\begin{array}{l}0 \\
\stackrel{0}{0}\end{array}$ & $\begin{array}{l}0 \\
\infty \\
\varrho\end{array}$ & $\begin{array}{l}\stackrel{\cap}{\longrightarrow} \\
\dot{I}\end{array}$ & $\begin{array}{l}0 \\
\stackrel{2}{\simeq}\end{array}$ \\
\hline \multicolumn{13}{|c|}{ June } \\
\hline 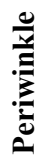 & $\begin{array}{c}0 \\
\stackrel{1}{n}\end{array}$ & $\stackrel{ }{\sim}$ & $\bar{a}$ & $\bar{r}$ & $\underset{\infty}{\sim}$ & $=$ & $\begin{array}{l}n \\
a \\
\alpha\end{array}$ & $\stackrel{\infty}{\varrho}$ & $\begin{array}{l}\hat{\infty} \\
\alpha\end{array}$ & $\stackrel{m}{\stackrel{0}{0}}$ & กิ & $\begin{array}{l}\infty \\
\stackrel{0}{0} \\
\varrho\end{array}$ \\
\hline 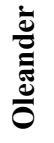 & $\stackrel{n}{n}$ & $\stackrel{\mathbb{N}}{\stackrel{N}{ }}$ & $\vec{m}$ & ñ & $\begin{array}{l}\hat{\infty} \\
\hat{n}\end{array}$ & $\stackrel{+}{\circ}$ & $\begin{array}{l}\infty \\
\infty \\
\infty\end{array}$ & $\underset{\infty}{\infty}$ & 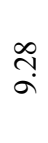 & $\begin{array}{l}\infty \\
\infty \\
\infty\end{array}$ & mे & $\stackrel{n}{n}$ \\
\hline \multicolumn{13}{|c|}{ July } \\
\hline 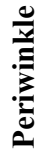 & $\underset{\overbrace{}}{O}$ & $\hat{\sigma}$ & $\stackrel{n}{\circ}$ & స̦. & $\stackrel{\infty}{\infty}$ & $\ddot{\sigma}$ & $\begin{array}{l}2 \\
\infty \\
0 \\
-\end{array}$ & 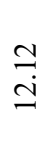 & $\begin{array}{l}\infty \\
\alpha\end{array}$ & $\stackrel{a}{n}$ & $\stackrel{\curvearrowright}{\stackrel{\vartheta}{g}}$ & $\begin{array}{l}\stackrel{\partial}{2} \\
\stackrel{g}{2}\end{array}$ \\
\hline 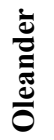 & ले & స్రి & $\underset{\infty}{\infty}$ & $\begin{array}{l}\overline{0} \\
\infty\end{array}$ & $\frac{\infty}{\infty}$ & $=$ & $\begin{array}{l}= \\
\dot{m}\end{array}$ & ָָ & $\stackrel{\infty}{\infty}$ & $\begin{array}{l}\hat{\infty} \\
\dot{ \pm}\end{array}$ & $\begin{array}{l}\infty \\
\stackrel{\sim}{\sim}\end{array}$ & $\begin{array}{l}\infty \\
\infty \\
n \\
n\end{array}$ \\
\hline \multicolumn{13}{|c|}{ August } \\
\hline 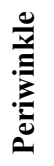 & $\begin{array}{l}\infty \\
\stackrel{+}{a} .\end{array}$ & ִָ & $\begin{array}{l}\stackrel{0}{+} \\
\text { aे }\end{array}$ & $\stackrel{\stackrel{m}{\sim}}{=}$ & $\begin{array}{l}\stackrel{\Xi}{\Xi} \\
=\end{array}$ & 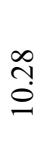 & $\stackrel{\infty}{=}$ & $\stackrel{\infty}{=}$ & $\stackrel{\text { f. }}{\beth}$ & 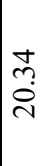 & 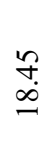 & $\begin{array}{l}\tilde{n} \\
\tilde{a}\end{array}$ \\
\hline 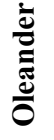 & $\begin{array}{l}\vec{n} \\
\stackrel{0}{0}\end{array}$ & $\begin{array}{l}\widehat{\sigma} \\
\sigma \\
\sigma\end{array}$ & $\begin{array}{l}\stackrel{\odot}{+} \\
=\end{array}$ & $\begin{array}{l}\cong \\
\Xi\end{array}$ & $\stackrel{\text { I }}{\text { I }}$ & $\stackrel{n}{\varrho}$ & $\begin{array}{l}\infty \\
\sim \\
\\
-\end{array}$ & $\begin{array}{l}\hat{\sigma} \\
\stackrel{0}{ }\end{array}$ & $\begin{array}{l}\infty \\
\stackrel{\infty}{0} \\
\stackrel{u}{u}\end{array}$ & 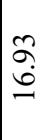 & ڤે & $\begin{array}{l}\bar{b} \\
\stackrel{a}{ }\end{array}$ \\
\hline
\end{tabular}

Table 2. Concentration of $\mathrm{Pb}$ in plant parts during the experimental period.

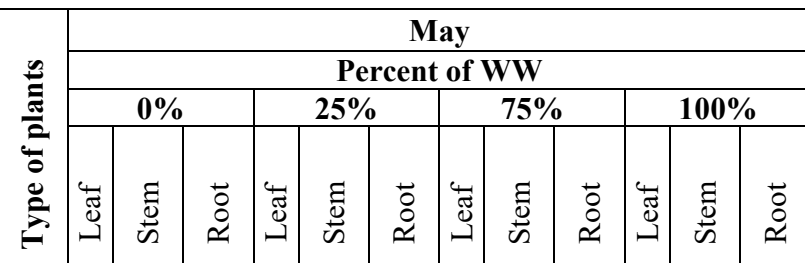

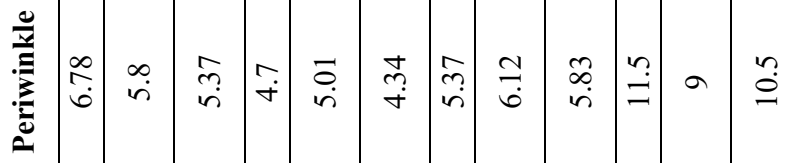

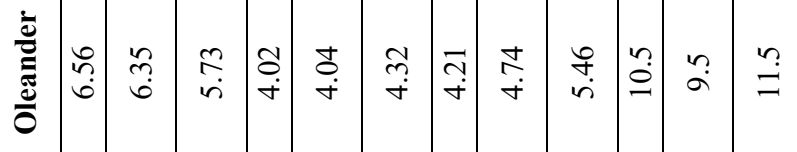

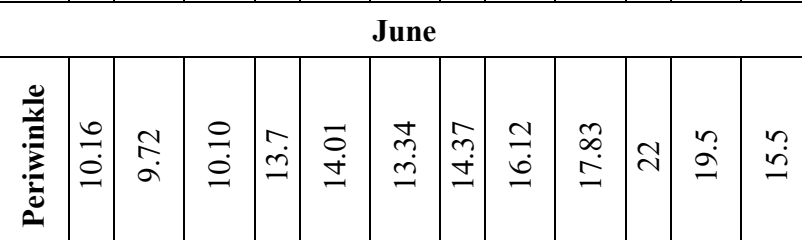

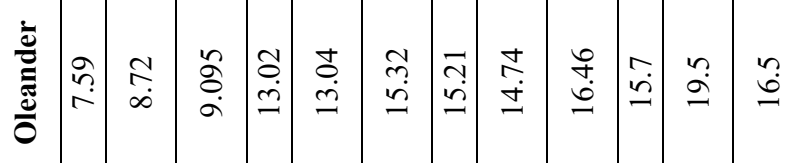
July

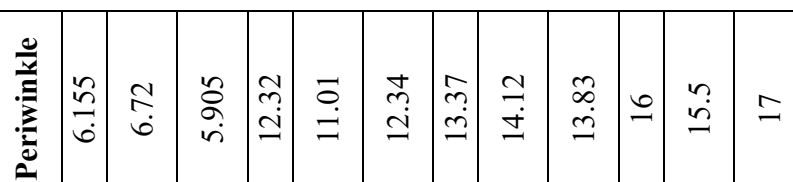

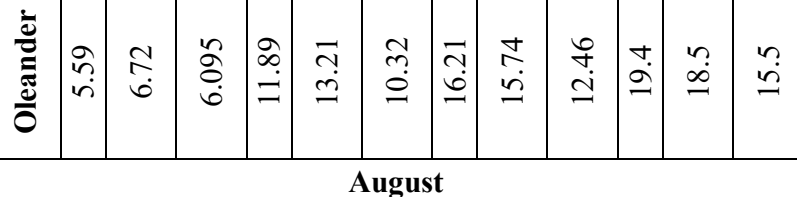

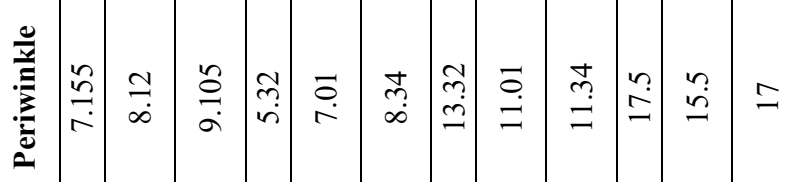

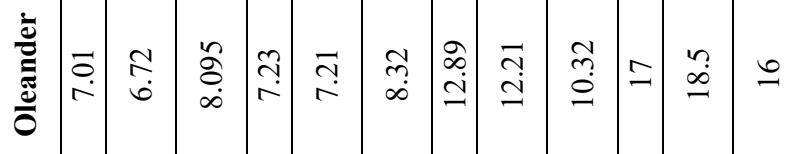




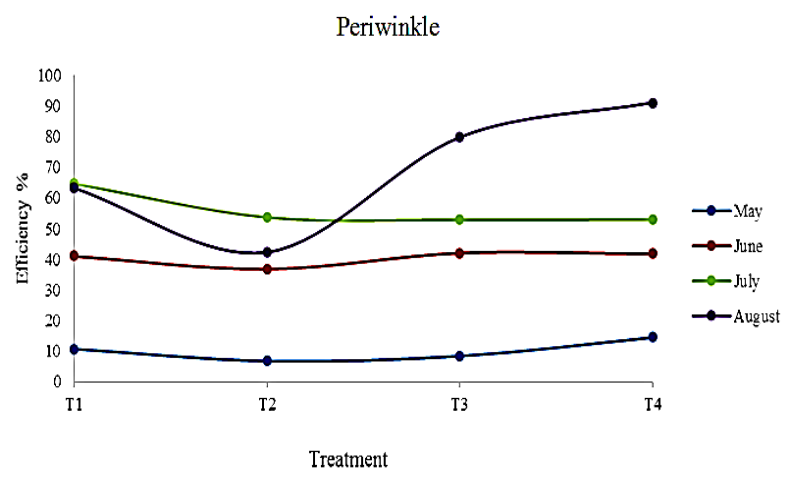

Fig. 1. Removal efficiency (\%) of $\mathrm{Pb}$ for Periwinkle.

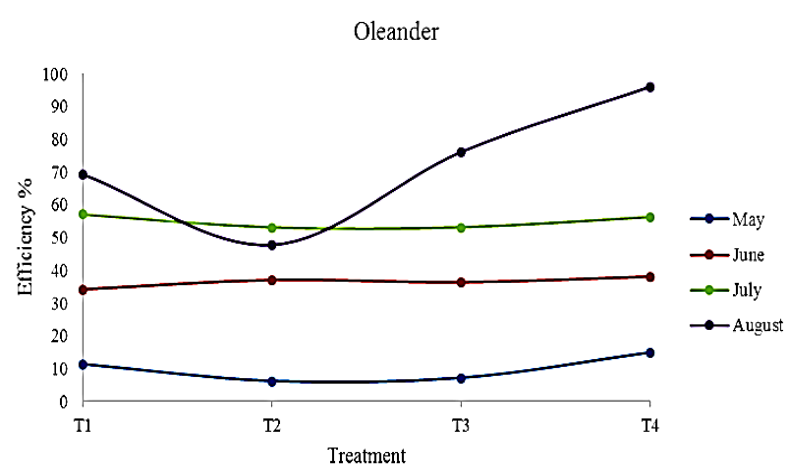

Fig. 2. Removal efficiency (\%) of $\mathrm{Pb}$ for Oleander.

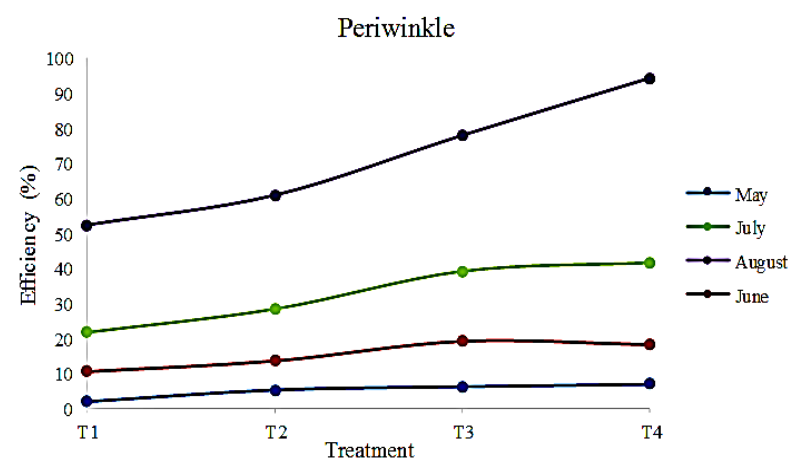

Fig. 3. Removal efficiency (\%) of $\mathrm{Cr}$ for Periwinkle.

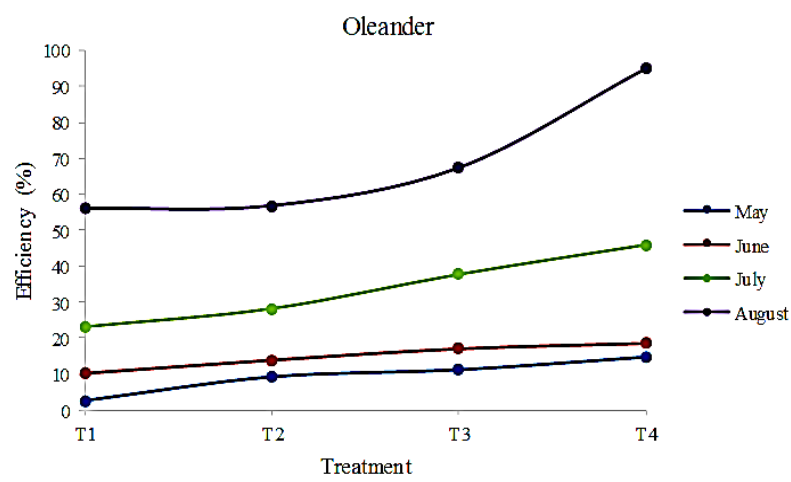

Fig. 4. Removal efficiency (\%) of $\mathrm{Cr}$ for Oleander.

\section{Acknowledgment}

The Authors thank and acknowledge the Ministry of Higher Education and Scientific Research, Research and Development Directorate for their support to construct the greenhouse in the University of Technology campus. We also cordially thank the Environmental Research Centre, University of Technology, Baghdad, Iraq for their scientific support. Special thanks to Mrs. Athmar Al-Mashhady, Environmental Research Centre, for her efforts in carrying out the laboratory analysis.

\section{References}

1. M. M. Rahman, S. M. Azirun, A.N. Boyce, "Enhanced Accumulation of Copper and Lead in Amaranth (Amaranthuspaniculatus), Indian Mustard (Brassica Juncea) and Sunflower (Helianthus annuus)" PLoS ONE, 8(5), e6294, (2013)..

2. A. Mojiri, "Phytoremediation of Heavy Metals from Municipal Wastewater by Typhadomingensis" African Journal of Microbiology Research, 6(3), 643-647, (2011).

3. O. Nathan, K. P. Njeri, O.E. Rang'ondi, C. J. Sarima, "The potential of Zea mays, Commelinabengelensis, Helianthus annuus and Amaranthushybridus for phytoremediation of waste water". An Interdisciplinary Journal of Applied Science: vol. 7, no.3, 2012.

4. A. H. M. J. Al-Obaidy, N. H. Hamza, E. Shakir, A. A. M. Al-Mashhady, "Assessment of some atmospheric heavy metals in selected sites within Baghdad city". Mesopotamia Environmental Journal, vol.2, no.3: pp. 42-46, (2016).

5. S. Sahay, A. Inam, S. Iqbal, "Effect of Wastewater Irrigation on Soil, Metal Tolerance and its Remediation by Four Oil Yielding Brassica Cultivars" Environmental Journal of Environmental Sciences, 4(2), 158-170, (2013).

6. EPA Environmental Protection Agency, "Introduction to Phytoremediation". Cincinnati, Ohio. (2000).

7. A.M. Mathew, "Phytoremediation of Heavy Metal Contaminated Soil." M.Sc., Thesis, Bachelor of Technology Cochin University of Science and Technology Cochin, Kerala, India, (2001).

8. S. Marin, S. Lacrimioara, R. Cecilia, "Evaluation of Performance Parameters for Trace Elements Analysis in Perennial Plants using ICP-OES Technique", J. Plant Develop, 18, 87-93, 20, (2011). 